Financial Risk and Management Reviews

2021 Vol. 7, No. 1, pp. 60-66.

$\operatorname{ISSN}(e): 2411-6408$

$\operatorname{ISSN}(p): 2412-3404$

DOI: 10.18488/journal.89.2021.71.60.66

(C) 2021 Conscientia Beam. All Rights Reserved.

check for
updates

\title{
PERFORMANCE EVALUATION OF CHINESE COMMERCIAL BANKS BASED ON THE MALMQUIST INDEX
}

(iD) Wenjing Xie ${ }^{1+}$
(iD) Meiling He
(iD) Guohui Huang
(iD Lu He
(iD Fan Lin
(iD Wen-Tsao Pan

\author{
1,2,3,1,5,6 Hunan University of Science and Engineering, School of Economics and \\ Management, Hunan, Yongzhou, Lingling, District, China. \\ 'Email:1269244811@qq.com Tel: 17077378829 \\ ${ }^{2}$ Email:1438758365@,qq.com Tel: 15399977785 \\ ${ }^{s}$ Email:2062705347@qq.com Tel:18176775344. \\ "Email:he1125@foxmail.com Tel 18373461057 \\ ${ }^{5}$ Email:1403561680@qq.com Tel: 18674686031 \\ ${ }^{6}$ Email: teacherp0162@,126.com Tel:13426703155
}

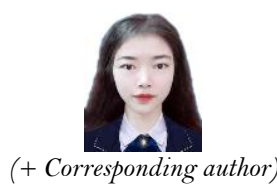

ABSTRACT

Commercial banks have the function of promoting the raising and rational distribution of funds in economic construction in China. Commercial banks are also important in promoting the smooth development of socialist economic activities and the development of national economy and other socialist productive economic activities. At present, one of the biggest difficulties faced by China's commercial banks is the improvement of their efficiency and competitiveness in the face of continuous development and change. This paper establishes the efficiency evaluation model of commercial banks using the DEA-based Malmquist index; it also uses a data envelopment analysis (DEA) to analyze the financial data of nine listed banks in China from 2011 to 2020, studies the efficiency of commercial banks in China, and finds the efficiency differences. Based on empirical research, this paper puts forward corresponding suggestions. The research shows that the key to dealing with this situation depends on the banks' effective utilization of scientific and technological innovation and technological progress. In order to achieve the goal of innovative and sustainable development of commercial banks, it is necessary to integrate the continuous developments of science and technology with finance.

Contribution/Originality: The paper's primary contribution is finding that in the face of continuous technological innovation and technological progress, the effective way to improve the performance of Chinese commercial banks is to effectively integrate technology and finance.

\section{INTRODUCTION}

With the development of China and the progress of technology, the financial industry is becoming more and more efficient, the growth of the market and the main bodies of operation are also increasing, and the competition in the Chinese and the international financial industries is becoming more and more fierce. The operating efficiency of commercial banks not only represents their sustainable development level, but also feeds back the potential of efficient resource allocation. As an important indicator of a company's operation, efficiency evaluation plays an important role in the sustainable development of banks. Banks can judge their own strength level through the results of efficiency evaluation, plan in advance and formulate the route of future development. The main activity of commercial banks is to offer industrial and commercial loans and deposits for profit. Commercial banks play a role in planning money, credit goods and other financial services. The existence of commercial banks is conducive to 
promoting capital flow, reducing the cost of transaction processes, saving transaction time, improving the efficiency of resource allocation and promoting economic development. Yu-Dan (2018) proposed the improvement of the efficiency of China's commercial banks by increasing the proportion of technology input, developing intermediary business, reducing the non-performing loan ratio, and increasing the capital adequacy ratio (Yu-Dan, 2018).The Zhao and Zhao (2021) representative cited the following reference papers: (Yu-Dan, 2018). Zhao and Zhao (2021), after much research in terms of scale efficiency, pure technical efficiency and operation efficiency, stated that listed commercial banks perform better than non-listed commercial banks. Therefore, one of the ways to improve the efficiency of commercial banks is to increase the listing construction of commercial banks (Yu-Dan, 2018). The operating efficiency of banks has great potential for development, and there are imbalances and mismatches in bank input and output. The aim of this study is to measure the financial data of nine listed banks in China from 2011 to 2020 through the DEA-based Malmquist index method, clearly understand the correlation between input and output indicators, explore the effect of technological progress on bank efficiency, and find answers on how to improve the efficiency of Chinese commercial banks.

\section{LITERATURE DISCUSSION}

Bank efficiency can reflect the competitiveness and operating level of banks in the industry. The level of resource allocation of banks is reflected by the ratio of their inputs and outputs. $\mathrm{Li}$ and $\mathrm{Hu}(2015)$ mentioned that, at this stage, there are three types of methods for exploring bank efficiency: One method is to use non-parametric data envelopment analysis (DEA) to explore bank efficiency; the second method is to analyze bank efficiency based on relevant financial indicators; the third method is to use the parameter analysis method to construct a multiple linear regression model using the cost of production function. Using the DEA-based Malmquist index method to analyze the financial data of nine listed banks in China from 2011 to 2020 is the main content of this article. DEA is a linear programming method based on the research of Farrell (1957), who analyzed the technical efficiency of only one input and one output and clarified a way to help companies analyze the efficiency of measurement under multiple input conditions. Charnes, Cooper, and Rhodes (1978) developed the CCR linear programming model to further analyze the technical efficiency of multiple inputs and outputs. DEA can be applied to a bank's input and output indicator system. In view of the different national conditions and economic environments, the interpretation of bank input and output is also different. It is easier for commercial banks to manipulate input factors, so the use of inputoriented models to evaluate efficiency is more in line with the actual situation. Zhang and Lei (2019) analyzed the financial data of 15 commercial banks from 2006 to 2015 as a sample and concluded that bank efficiency decreases from high to low from joint-stock banks, city commercial banks to state-owned banks, and the difference between these three diminishes with the passage of time. Feng (2020) found that, based on the data envelopment method, excessive input and insufficient output are due to uneven resource allocation and insufficient management capabilities. Banks in China need to optimize the allocation of resources through internal adjustments to solve the problem of low operating capabilities and improve their efficiency. Yang, Chen, and Tan (2020) used a two-stage slack-based measure (SBM) model that considers undesired outputs to analyze the efficiency of 24 commercial banks in China, and found that the traditional DEA model may overestimate the efficiency of banks (Yang et al., 2020). An, Hou, and Li (2021) concluded, based on the efficiency measurement of the three-stage DEA-Tobit model, that increasing the total amount of commercial bank loans can promote economic efficiency and resource allocation efficiency while hindering the improvement of management technology efficiency. One of the conditions for realizing the rapid development of economic benefits is to improve the innovation ability of commercial banks. Cao and Du (2021) analyzed the financing efficiency of listed commercial banks that issue preferred shares in China. The research data showed that one of the ways to improve financing efficiency is to allow listed commercial banks to issue equity-type preferred shares, which can increase the company's financial leverage and reduce the debt-to-asset 
ratio. As a result of their study, Cao \& Du called on commercial banks to promote technological innovation. Call on commercial banks to promote technological innovation.

\section{RESEARCH METHOD}

\subsection{DEA-based Malmquist Index Method}

The data envelopment analysis (DEA) model is an analytical tool used to identify the efficiency of resource allocation within a company; however, one of its disadvantages is that it cannot analyze the numerical changes of efficiency in different periods. Traditional DEA models can be divided into the CCR model (based on constant returns to scale) and the BCC (Banker Charnes Cooper) model (based on variable returns to scale), which is also the difference between them. Fare, Grosskopf, and Norris (1994) proposed the DEA-based Malmquist model, which combines the Malmquist index theory with the DEA method to describe the dynamic changes in efficiency.

Suppose there is $n$ decision-making unit (DMU) and each DMU obtains $s$ types of outputs through $m$ types of inputs in the $t$ period. $x^{t}{ }_{j}=\left(x^{t}{ }_{1 j}, x^{t}{ }_{2 j}, \ldots, x_{m j}^{t}\right)^{T}$ represents the investment index value of the Jth DMU in

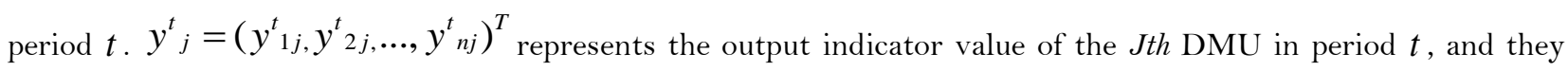
are all positive numbers $(t=1,2, \ldots, T)$. Assuming that $\left(x^{t}, y^{t}\right)$ represents the input and output of period $t,\left(x^{t+1}, y^{t+1}\right)$ represents the input and output of the $\mathrm{t}+1$ period. In $D^{t}{ }_{c}\left(x^{t}, y^{t}\right) 、 D^{t+1}{ }_{c}\left(x^{t+1}, y^{t+1}\right)$, the $c$ return to scale is stable, and $D_{c}^{t}\left(x^{t}, y^{t}\right) 、 D^{t+1}{ }_{c}\left(x^{t+1}, y^{t+1}\right)$ is the output distance function in the corresponding period. Under the technical conditions in period $t$, the change in technical efficiency from period $t$ to period $t+1$ is expressed as Equation 1 and Equation 2, respectively:

$$
\begin{aligned}
M^{t} & =\frac{D^{t}{ }_{c}\left(x^{t+1}, y^{t+1}\right)}{D^{t}{ }_{c}\left(x^{t}, y^{t}\right)} \\
M^{t+1} & =\frac{D^{t+1}{ }_{c}\left(x^{t+1}, y^{t+1}\right)}{D^{t+1}{ }_{c}\left(x^{t}, y^{t}\right)}
\end{aligned}
$$

We calculate the geometric mean of the two Malmquist indices in Equation 1 and Equation 2 to obtain Equation 3:

$$
t f p=M^{t+1}\left(x^{t+1}, y^{t+1}, \quad x^{t}, y^{t}\right)=\left[\frac{D^{t}{ }_{c}\left(x^{t+1}, y^{t+1}\right)}{D^{t}{ }_{c}\left(x^{t}, y^{t}\right)} \times \frac{D^{t+1}{ }_{c}\left(x^{t+1}, y^{t+1}\right)}{D^{t+1}{ }_{c}\left(x^{t}, y^{t}\right)}\right]^{\frac{1}{2}}
$$

The Malmquist index is combined with DEA to analyze the development of efficiency changes by calculating the change in productivity from period to period. The differences between total factor productivity and factor productivity are as follows: Total factor productivity refers to the comprehensive productivity of various factors in a certain period of a business process. The factors here refer to all other material factors except labor and capital, including organizational innovation, technological progress, and production innovation.

Scale efficiency change (Sech) and pure technical efficiency change (Pech) constitute technical efficiency change (EFFch), technical efficiency (EFFch) and technological progress (Tech) constitute total factor productivity (TFP), and Equation 4 is obtained:

$$
\mathrm{TFPch}=\mathrm{TECHch} \times \mathrm{EFFch}=\mathrm{TECHCh} \times \mathrm{Pech} \times \mathrm{Sech}
$$


EFFch represents the change in technical efficiency from period t to period $t+1$; TECHch represents the technological progress index from period t to period $t+1$; TFPch represents the change of TFP from period $t$ to period $t+1$; Sech represents the change of scale efficiency from period t to period $t+1$; Pech represents the pure technical efficiency change from period $t$ to period $t+1$.

Input-oriented and output-oriented are two methods of the DEA-based Malmquist index method: (1)How to minimize the input when the output level is determined;(2)How to maximize output when the input level is determined. Since bank input factors are easier to control than output factors, a more appropriate method is the output-oriented DEA-based Malmquist index method.

\subsection{Selection of Indicators}

This paper selects nine listed banks in China as samples: Bank of China, Industrial and Commercial Bank of China (ICBC), Agricultural Bank of China, Bank of Communications, Construction Bank, Industrial Bank, China CITIC Bank, China Everbright Bank, and Minsheng Bank. The relevant indicator data comes from the financial statements of each bank for each year. Input and output indexes constitute the efficiency evaluation index system. We referred to previous studies to select bank operating expenses, total shareholder equity, and deposits as input indicators, and we selected total profit and interest income as output indicators (see Table 1).

Table-1. Input and output indicators of efficiency.

\begin{tabular}{c|c|c|c}
\hline Indicator type & Index & Variable & Unit \\
\hline \multirow{3}{*}{ Input indicators } & Operating expenses & $\mathrm{X}_{1}$ & 100 million yuan \\
\cline { 2 - 4 } & Deposits taken & $\mathrm{X}_{2}$ & 100 million yuan \\
\cline { 2 - 4 } & Total shareholder equity & $\mathrm{X}_{3}$ & 100 million yuan \\
\hline \multirow{2}{*}{ Output indicators } & Interest income & $\mathrm{Y}_{1}$ & 100 million yuan \\
\cline { 2 - 4 } & Total profit & $\mathrm{Y}_{2}$ & 100 million yuan \\
\hline
\end{tabular}

\section{EMPIRICAL ANALYSIS}

The Malmquist index and DEA can analyze the dynamic changes of technological progress efficiency. This situation is also applicable to commercial banks. In Table 2 , the technological progress efficiency of the nine listed banks from 2011 to 2020 is decomposed and the results are as follows:

Table-2. The average Malmquist decomposition index of the technological progress of commercial banks in each year

\begin{tabular}{c|c|c|c|c|c}
\hline & $\begin{array}{c}\text { Technical } \\
\text { Efficiency } \\
\text { Index } \\
\text { (EFFch) }\end{array}$ & $\begin{array}{c}\text { Technological } \\
\text { Progress } \\
\text { Index (Tech) }\end{array}$ & $\begin{array}{c}\text { Pure Technical } \\
\text { Efficiency } \\
\text { Index (Pech) }\end{array}$ & $\begin{array}{c}\text { Scale } \\
\text { Efficiency } \\
\text { Index } \\
\text { (Sech) }\end{array}$ & $\begin{array}{c}\text { Total Factor } \\
\text { Productivity } \\
\text { Index (TFP) }\end{array}$ \\
\hline $2011-2012$ & 0.995 & 1.014 & 0.988 & 1.008 & 1.010 \\
\hline $2012-2013$ & 1.006 & 1.004 & 0.997 & 1.011 & 0.983 \\
\hline $2013-2014$ & 0.975 & 1.009 & 0.992 & 0.969 & 0.984 \\
\hline $2014-2015$ & 0.920 & 1.004 & 0.951 & 1.061 & 0.924 \\
\hline $2015-2016$ & 0.905 & 1.235 & 0.853 & 1.163 \\
\hline $2016-2017$ & 1.007 & 1.000 & 1.083 & 0.929 & 1.007 \\
\hline $2017-2018$ & 0.956 & 1.000 & 0.987 & 0.970 & 0.956 \\
\hline $2018-2019$ & 0.977 & 1.000 & 1.021 & 0.969 & 0.977 \\
\hline Average & 0.942 & 1.000 & 0.974 & 0.983 & 0.997 \\
\hline
\end{tabular}

Analysis was carried out according to the values of the technical efficiency (EFFch) index, total factor productivity (TFP) index, scale efficiency (Sech) index, technological progress (Tech) index, and pure technical efficiency (Pech) index, and the values were compared with 1. If the value of TFP is greater than 1, it indicates that the total factor efficiency has improved; if the value of EFFch is greater than 1, it indicates that there is technical 
efficiency; if the Tech value is greater than 1, it indicates that there is technological progress; if the value of Sech is greater than 1, it indicates that the expansion of the scale improves efficiency; if the value of Pech is larger than 1, it indicates that there are other factors that can promote efficiency. It can be seen from Table 2 that, on the whole, the $\mathrm{M}$ index of Chinese commercial banks from 2011 to 2020 is less than 1, indicating that the efficiency of technological innovation of Chinese commercial banks has declined, with an average annual decline of $0.3 \%$, where the decline from 2014 to 2015 reached $7.6 \%$. When Tech is greater than 1, 1 is greater than Sech, and most of $\mathrm{EFF}$ ch is less than 1. If the $\mathrm{M}$ value is less than 1, it can be concluded that the nine commercial banks sampled from 2011 to 2020 have shown a decline in technological innovation efficiency. From this, we can see the scale efficiency change index of less than 1 is an important factor in the decline in efficiency of technological innovation of the sampled commercial banks. In addition, the average value of Sech is less than 1, and Pech fluctuates around 1, which means that it is in the stage of diminishing returns to scale. This means that the scale of commercial banks has not reached the optimal level with the continuous introduction of new technologies and technological progress. The degree of progress does not match the scale, and it has not reached the stage of increasing scale benefits. The operating efficiency of banks still has a lot of room for improvement, and the imbalance and mismatch of bank input and output hinders the improvement of the efficiency level regarding technological innovation. The detailed Malmquist index of each commercial bank's technological innovation efficiency and its decomposition are detailed in Table 3 below.

Table-3. Malmquist index and its decomposition of urban technological innovation efficiency of commercial banks.

\begin{tabular}{l|c|c|c|c|c}
\hline & EFFch & Tech & Pech & Sech & TFP \\
\hline People's Bank of China & 0.969 & 1.007 & 0.986 & 0.987 & 0.974 \\
\hline Industrial and Commercial Bank & 0.952 & 1.207 & 1.000 & 0.952 & 1.187 \\
\hline Agricultural Bank of China & 0.961 & 1.005 & 0.994 & 0.970 & 0.965 \\
\hline Bank of Communications & 0.968 & 1.003 & 0.969 & 0.999 & 0.971 \\
\hline China Construction Bank & 0.958 & 1.009 & 1.005 & 0.960 & 0.965 \\
\hline China's Industrial Bank & 0.963 & 1.018 & 0.975 & 0.991 & 0.980 \\
\hline China CITIC Bank & 0.970 & 1.002 & 0.982 & 0.989 & 0.972 \\
\hline China Everbright Bank & 0.971 & 1.002 & 0.960 & 1.013 & 0.973 \\
\hline China Minsheng Bank & 0.970 & 1.013 & 0.973 & 0.998 & 0.982 \\
\hline
\end{tabular}

In the table, EFFch, Tech, Pech, Sech and TFP respectively represent technical efficiency index, technical progress index, pure technical efficiency index, scale efficiency index and total factor productivity index.

From the perspective of banks, Industrial and Commercial Bank of China (ICBC), China Construction Bank and China Everbright Bank have developed better than the other six banks in the past ten years. It shows that the resource structure allocation of these three banks is relatively reasonable. The technological progress indexes (Tech) of all nine banks are greater than 1, which shows effectiveness; the pure technical efficiency index of the Industrial and Commercial Bank of China and China Construction Bank is equal to 1 or more than 1, respectively, which means that the invested resources are used efficiently; ICBC's TFP is greater than 1, indicating that the efficiency of all factors has improved; Everbright Bank's scale efficiency index (Sech) is greater than 1, indicating that the expansion of scale has improved efficiency. ICBC recently increased its investment in financial science and technology innovation. It has not only achieved results in $5 \mathrm{G}$, cloud computing, and big data, but has also achieved great results in areas such as artificial intelligence and blockchain. In 2020, ICBC's investment in information technology increased by $20 \%$ year-on-year and it invested 207.8 billion yuan in funds. At the same time, China Construction Bank focused on building a new generation of core systems in 2010 and won the People's Bank of China's “2017 Banking Technology Development Award” to form efficient financial technology innovation capabilities. In terms of technology-driven processes, China Construction Bank has established a series of platforms in cloud computing, artificial intelligence, $5 \mathrm{G}$, blockchain and other fields, and its innovative business continues to 
develop. Everbright Bank insists on promoting business development with innovative technology and has established a scientific and technological innovation fund, including scientific research expenses and marketing. Everbright Bank also established the Everbright Digital Finance Academy. While cooperating with a number of institutions with technological innovation as the core theme, it launched a double investment plan in science and technology, and it supported financial technology innovation projects in terms of employees by cultivating innovative talents.

\section{CONCLUSION}

Based on the analysis of the financial data of nine listed banks in China from 2011 to 2020, we can draw the following conclusions. First, commercial banks need to adapt to the changing times and circumstances, increase capital investment, strengthen technological empowerment, further support businesses, improve customer service capabilities, and promote their own high-quality development. Second, from 2011 to 2020, the technical progress indexes of the nine listed banks showed a trend of volatility and that technology was steadily improving. Third, we have calculated that the technological progress indexes (Tech) are greater than 1, the scale efficiency change indexes (Sech) are less than 1, most of the technical efficiency indexes (EFFch) are less than 1, and the M value is less than 1. Therefore, it can be concluded that the efficiency of technological innovation of the nine commercial banks sampled from 2011 to 2020 has declined. Fourth, strengthening financial innovation capabilities can improve the efficiency of Chinese commercial banks. Technological attributes are the core and most basic attributes of new finance. One of the ways to improve the competitiveness of commercial banks is to promote the production of new financial products by increasing capital investment in innovative technologies. Finally, the overall operating performance of these nine banks is diminishing returns to scale. Banks can reduce the corresponding costs by reducing investment, which can improve their operating efficiency.

Funding: This study received no specific financial support.

Competing Interests: The authors declare that they have no competing interests.

Acknowledgement: All authors contributed equally to the conception and design of the study.

\section{REFERENCES}

An, B., Hou, Z., \& Li, C. (2021). Research on the economic benefits of my country's commercial banks— based on the threestage DEA-tobit Model's Efficiency Measurement and influencing sactors analysis. Journal of Jianghan University, $38(1), 86-128$.

Cao, C., \& Du, W. (2021). Analysis of the financing efficiency of my country's listed commercial banks issuing preferred shares. Accounting Friends, $2021(06), 81-87$.

Charnes, A., Cooper, W. W., \& Rhodes, E. (1978). Measuring the efficiency of decision making unit. European Journal of Operational Research, 1978(2), 429- 444.

Fare, R., Grosskopf, S., \& Norris, M. (1994). Productivity growth, technical progress, and efficiency change in industrialized countries. American Economic Review, 84(5), 1040-1044.

Farrell, M. J. (1957). The measurement of productive efficiency. Journal of the Royal Statistical Society: Series A (General), 120(3), 253-281.

Feng, Y. (2020). The efficiency analysis of my country's listed commercial banks based on data envelopment method. Time Finance, 2020(16), 65-67.

Li, P., \& Hu, J. (2015). The dynamic evolution of the efficiency of my country's commercial banks—based on the DEAMalmquist non-parametric data envelopment analysis method. Journal of Chizhou University, 29(02), 63-65.

Yang, J., Chen, Y., \& Tan, C. (2020). Study on the efficiency evaluation of China's banking industry based on the measurement of slack variables. Journal of Hefei University of Technology, 43(9), 1281-1287. 
Yu-Dan, X. (2018). Efficiency comparison of Chinese and foreign commercial banks based on DEA Model. Journal of Hubei University of Economics, $16(5), 46-52$.

Zhang, T., \& Lei, C. (2019). An empirical analysis of the measurement of the efficiency of my country's commercial banks and Its influencing factors-based on the panel data of 15 banks. Journal of Xi'an University of Finance and Economics, 32(04), 7581.

Zhao, F., \& Zhao, J. (2021). Using the DEA model to analyze and countermeasures to the problems in the operating efficiency of city commercial banks. Economist, $2021(05), 106-114$.

Views and opinions expressed in this article are the views and opinions of the author(s), Financial Risk and Management Reviews shall not be responsible or answerable for any loss, damage or liability etc. caused in relation to/arising out of the use of the content. 